Article

\title{
Extending the Cultivation Period of Undaria pinnatifida by Using Regional Strains with Phenotypic Differentiation along the Sanriku Coast in Northern Japan
}

\author{
Yoichi Sato ${ }^{1,2, *}$, Tomonari Hirano ${ }^{2,3}\left[\right.$, , Hiroyuki Ichida ${ }^{2}$, Nobuhisa Fukunishi ${ }^{2}$, Tomoko Abe ${ }^{2}$ \\ and Shigeyuki Kawano ${ }^{4}$ \\ 1 Riken Food Co., Ltd., 2-5-60 Miyauchi, Tagajyo 985-0844, Japan \\ 2 RIKEN Nishina Center for Accelerator-Based Science, 2-1 Hirosawa, Wako, Saitama 351-0198, Japan; \\ tomonari-hirano@cc.miyazaki-u.ac.jp (T.H.); ichida@riken.jp (H.I.); fukunisi@ribf.riken.jp (N.F.); \\ tomoabe@riken.jp (T.A.) \\ 3 Faculty of Agriculture, University of Miyazaki, 1-1 Gakuen-Kibanadai Nishi, Miyazaki 889-2192, Japan \\ 4 Future Center Initiative, The University of Tokyo, 178-4-4 Wakashiba, Kashiwa, Chiba 277-0871, Japan; \\ kawano@edu.k.u-tokyo.ac.jp \\ * Correspondence: yoi_sato@rikenfood.co.jp
}

check for

updates

Citation: Sato, Y.; Hirano, T.; Ichida, H.; Fukunishi, N.; Abe, T.; Kawano, S. Extending the Cultivation Period of Undaria pinnatifida by Using Regional Strains with Phenotypic Differentiation along the Sanriku Coast in Northern Japan. Phycology 2021, 1, 129-142. https://doi.org/ 10.3390 /phycology 1020010

Academic Editor: Peer Schenk

Received: 20 October 2021

Accepted: 29 November 2021

Published: 6 December 2021

Publisher's Note: MDPI stays neutral with regard to jurisdictional claims in published maps and institutional affiliations.

Copyright: (c) 2021 by the authors. Licensee MDPI, Basel, Switzerland. This article is an open access article distributed under the terms and conditions of the Creative Commons Attribution (CC BY) license (https:/ / creativecommons.org/licenses/by/ $4.0 /)$.

\begin{abstract}
The Sanriku district is one of the largest Undaria pinnatifida (Wakame) cultivation areas in Japan. However, the production has steadily declined in recent years due to the high retirement rate among fishers. Extending the cultivation period is a potential way to improve productivity by decentralizing the workforce through the production process. We aimed to investigate the phenotypic differentiation between regional strains of $U$. pinnatifida collected from Matsushima Bay (MAT) and Hirota Bay (HRT) in the Sanriku district through a cultivation trial to verify the application for the purpose of extending the cultivation period. The growth of MAT was better than that of HRT when the cultivation started earlier (i.e., 9 and 19 October 2014); in contrast, HRT outperformed MAT when the cultivation started later (6 November and 12 December 2014). The yield of MAT reached over the standard amount in the Sanriku district in February. On the other hand, the yield of HRT reached over this value in April. Furthermore, the photosynthetic performance and nutrient uptake rates differed between MAT and HRT, indicating that the differences may result in maturation characteristics. According to these results, the combined use of MAT and HRT would be a valuable strategy by which to extend the cultivation period.
\end{abstract}

Keywords: cultivation; macroalga; nutrient uptake rate; Undaria pinnatifida; Wakame

\section{Introduction}

Kelps are utilized globally as edible foods and energy sources because of their high primary productivity and great nutrition [1,2]. Undaria pinnatifida (Japanese vernacular name: "Wakame") is a major industrially produced species of kelp that has been cultivated in northern Asia for over half a century [3]. It is regarded as a healthy food due its many bioactive effects [4-7], and harvest and cultivation trials have been undertaken in various regions outside northern Asia since the 1980s [8,9].

Although the market demand has increased to meet the requirement of customers, the yield of $U$. pinnatifida in Japan has decreased over recent years. For example, in the Sanriku district (Iwate and Miyagi Prefectures), the principal U. pinnatifida production area in Japan, the total harvest declined from 49,872 to 21,771 t between 1999 and 2019 [10]. The decrease is correlated with a declining number of fishers; for example, the number working for Undaria cultivation at Iwate Prefecture in 2018 was 898, almost one-fifth of that in 1998. Furthermore, $35 \%$ of all fishers are over 65 years old, and $76.7 \%$ do not have successors [11]. Therefore, the decrease in number and aging of fishers seriously threaten the viability of the Undaria industry. In addition, Undaria farming in the Sanriku district requires a high 
workforce concentration over a short period. Sporelings are generally set into the culture rope in the sea from October to the end of November. Intensive harvesting is generally carried out in March and April. These highly time-restrictive cultivation schemes impede the scaling-up of the cultivation with a limited workforce. Therefore, there is a need to extend the cultivation period and harvesting time to equalize the daily cultivation tasks by developing aquaculture technology and appropriate cultivars.

In order to achieve higher productivity in the aquaculture of $U$. pinnatifida, previous studies have investigated the characteristics of heritability [12] and heterosis [13], and selective breeding has been applied [14-18]. Gao et al. [19] showed that Undaria sporophytes from a warmer site (Naruto, southern Japan) had significantly greater photosynthetic activities at high temperatures and higher nitrogen accumulation capacities than those from colder sites (Matsushima and Okirai bays, Sanriku coast in northeastern Japan). They concluded that sporophytes from Naruto had a greater tolerance to high temperatures and low-nutrient conditions, and that they could be introduced as parental stock in northern Japan. We previously investigated the phenotypic differences among $U$. pinnatifida plants cultivated at six different sites in Japan, and identified the ecotype-dependent characteristics in their growth and nutrient uptake kinetics [20]. Based on this result, our past studies compared the growth rates among regional strains through a common garden experiment using a novel tank culture system [21,22]. This showed that sporophytes from Matsushima Bay (MAT) in Miyagi Prefecture grow faster than other sporophytes, including those used at Hirota Bay (HRT) in Iwate Prefecture, suggesting that these differences are attributed to genotypes [22]. Fishers of the Sanriku district empirically used the techniques to shift the harvest time by using different phenotypic variants with different growth rates. However, these variants' growth patterns and physiological characteristics have not been quantitatively verified, and the scientific evidence has been insufficient.

In the present study, we focused on comparing the phenotypic differences between regional strains via a cultivation trial under experimental aquaculture conditions and evaluating the physiological responses to temperature. In order to achieve this, two regional strains-MAT and HRT-identified in previous studies [20,22], were used. The cultures were begun on five different dates, from September to December. Their morphological characteristics were observed in order to confirm the differences in their growth patterns, and to compare their photosynthesis rates and nutrient uptake kinetics. We also discuss the potential application of these different regional strains in the Undaria cultivation industry.

\section{Materials and Methods}

\subsection{Preparing the MAT and HRT Strains}

Two regional strains in the Sanriku district were used for the present study. First, the regional strain used for industrial cultivation in Matsushima Bay, Miyagi Prefecture $\left(38^{\circ} 32^{\prime} \mathrm{N}, 141^{\circ} 31^{\prime} \mathrm{E}, \mathrm{MAT}\right)$ was originally introgressed from Kinkasan $\left(38^{\circ} 30^{\prime} \mathrm{N}, 141^{\circ} 55^{\prime} \mathrm{E}\right)$, which is located $30 \mathrm{~km}$ northeast of MAT, and lies in the mixture area of the Oyashio and Kuroshio current [22]. Second, the regional strain used for industrial cultivation in Hirota Bay, Iwate Prefecture $\left(38^{\circ} 98^{\prime} \mathrm{N}, 141^{\circ} 71^{\prime} \mathrm{E}, \mathrm{HRT}\right)$ originated from wild sporophytes in Hirota Bay. Ten single-isolated sporophytes were selected from each strain, and were transferred to a tank system termed the "circulation and floating culture system" (CFCS) [21], where they were cultivated for two months at $10^{\circ} \mathrm{C}$ under a $12 \mathrm{~h}: 12 \mathrm{~h} \mathrm{~L}: \mathrm{D}$ cycle, with light of 80-100 $\mu \mathrm{mol}$ photons $\mathrm{m}^{-2} \mathrm{~s}^{-1}$, until the sporophylls formed. The largest plants were then selected, and spores were induced from their sporophylls. The resulting gametophytes from each strain were incubated in PESI medium [23] at $20{ }^{\circ} \mathrm{C}$, with a light intensity of $20 \mu \mathrm{mol}$ photons $\mathrm{m}^{-2} \mathrm{~s}^{-1}$ and a $12 \mathrm{~h}$ photoperiod.

\subsection{Sporeling Production}

The MAT and HRT gametophytes were separately maintained in $9 \mathrm{~cm}$ diameter plastic Petri dishes. The dishes contained $30 \mathrm{~mL}$ of PESI medium, were kept at $20{ }^{\circ} \mathrm{C}$ and a $20 \mu \mathrm{mol}$ photons $\mathrm{m}^{-2} \mathrm{~s}^{-1}$ light intensity, and were subjected to a $12 \mathrm{~h}$ photoperiod 
to promote growth (Figure 1a). Sporelings were produced from the gametophytes by a partially modified version of the technical manual in Tokushima Prefecture in Japan [24]. In brief, each gametophyte (male and female) from MAT and HRT was transferred to a $300 \mathrm{~mL}$ Erlenmeyer flask containing $200 \mathrm{~mL}$ PESI medium, and was then shredded to approximately 10 cells by a microblender (T 18 digital Ultra-Turrax ${ }^{\circledR}$; IKA, Osaka, Japan). In order to prepare a substrate for the sporelings, nylon fiber string was wound around a $13 \mathrm{~cm}$ square stainless steel frame, which was sterilized by boiling and then thoroughly dried. Next, the shredded gametophytes were poured into a plastic vat containing the PESI medium [23], and the substrate was soaked in the medium. The gametophytes were subsequently attached to the substrate by absorption, and the inoculated substrates were placed in an aquarium containing $7.5 \mathrm{~L}$ of quarter-strength PESI medium.

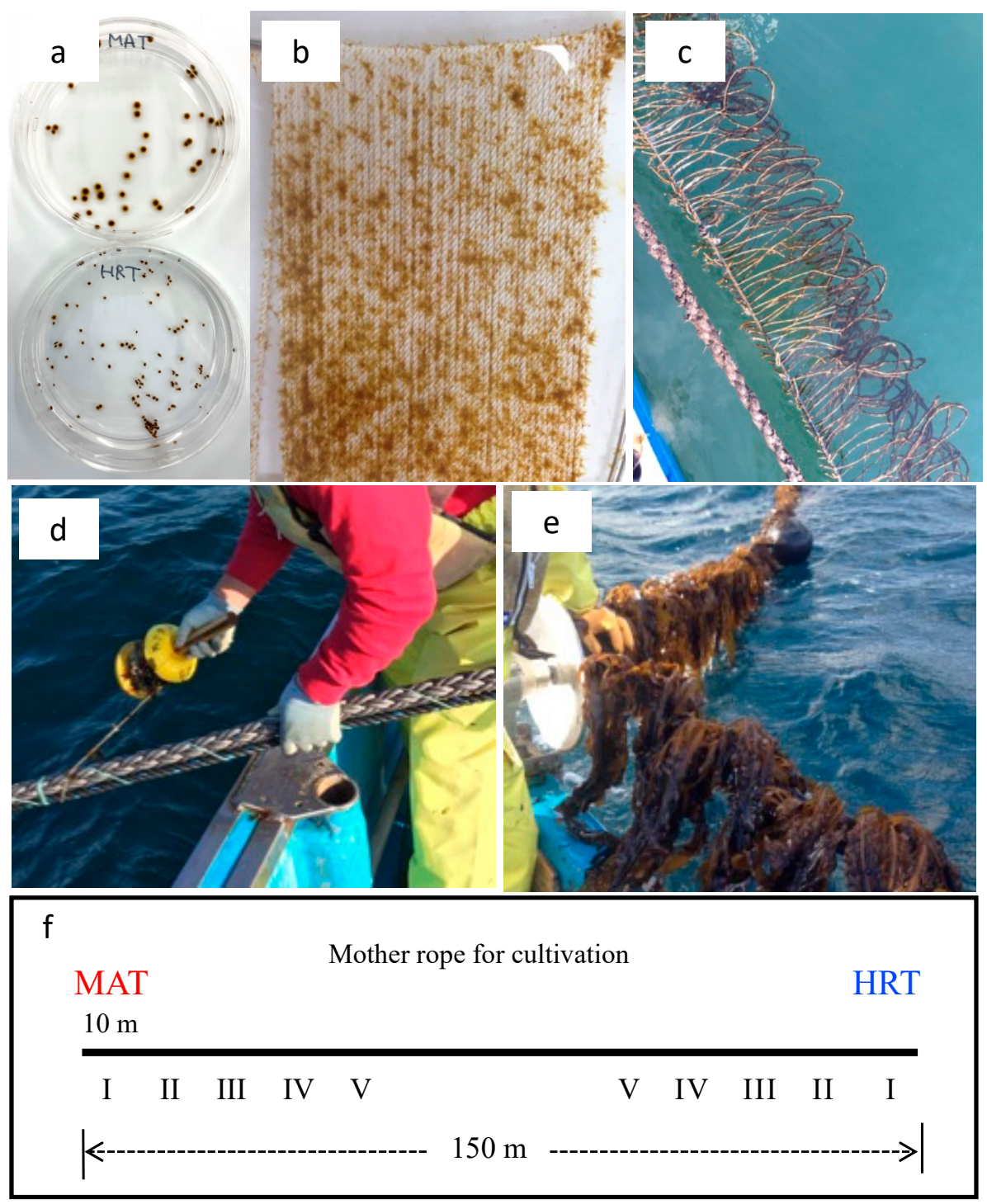

Figure 1. Photographs and a schematic diagram of the cultivation tests. (a) Gametophytes from regional strains of Undaria pinnatifida; (b) sporelings attached to fibers wound around a stainless steel frame; (c) the acclimatization of the sporelings to marine conditions at the marine cultivation farm; (d) setting the sporelings on the mother cultivation rope; (e) collected thalli from $1 \mathrm{~m}$ of the mother rope to measure the yield and morphological characteristics; and (f) diagram of the 150-m-long mother rope and the setting of MAT and HRT, which were cultivated from each end of the mother rope. I-V indicate the dates on which the sporelings were set and the cultivation began. These were as follows: set I, 14 September; set II, 9 October; set III, 19 October; set IV, 6 November; and set V, 12 December. 
During the first week, the substrates were incubated at a temperature of $20{ }^{\circ} \mathrm{C}$ and a light intensity of $40 \mu \mathrm{mol} \mathrm{m} \mathrm{m}^{-2} \mathrm{~s}^{-1}$ with a $12 \mathrm{~h}$ photoperiod. In each subsequent week, the light intensity was increased by $20 \mu \mathrm{mol} \mathrm{m} \mathrm{m}^{-2} \mathrm{~s}^{-1}$. In addition, the photoperiod was reduced to $11 \mathrm{~h}$ on week 3 and $10 \mathrm{~h}$ on week 4 . At week 5, when visible sporophytes were observed on the fiber (Figure 1b), the substrates were transferred to an aquarium with running seawater. The sporelings were transferred to a cultivation farm in the sea approximately 10 days before the marine cultivation started. The strings were tied onto ropes, which were hung at a depth of $50 \mathrm{~cm}$ in Hirota Bay, Iwate Prefecture (Figure 1c). The sporeling production was carried out five times.

The marine cultivation was carried out at Hirota Bay. A rope measuring $150 \mathrm{~m}$ in length and $50 \mathrm{~mm}$ in diameter was used as the mother rope, which is the standard in Iwate Prefecture. The sporophyte strings were cut into $3 \mathrm{~cm}$ sections and inserted at $30 \mathrm{~cm}$ intervals along a 3-mm-diameter nylon rope for the sporelings. The MAT and HRT sporelings were then set from different ends along the mother rope on five different dates in 2014 (set I: 14 September; set II: 9 October; set III: 19 October; set IV: 6 November; set V: 12 December), with $10 \mathrm{~m}$ intervals between each set (Figure $1 \mathrm{~d}-\mathrm{f}$ ). Before the total length of the sporophytes reached about $1 \mathrm{~m}$, the number of individuals was pruned to 80-120 per $1 \mathrm{~m}$ of aquaculture rope according to the fisherman' $\mathrm{s}$ experiences.

\subsection{Environmental Measurements}

The seawater temperature at the cultivation farm was measured every 15-20 days. A $300 \mathrm{~mL}$ seawater sample was also collected when the temperature was measured. The nitrate $\left(\mathrm{NO}_{3}-\mathrm{N}\right)$, ammonium $\left(\mathrm{NH}_{4}-\mathrm{N}\right)$, and phosphate $\left(\mathrm{PO}_{4}-\mathrm{P}\right)$ concentrations were measured using an automated analyzer (QuAAtro 2-HR; BLTEC, Osaka, Japan). The average seawater temperature between 1995 and 2013 was obtained from the Hirota Bay Fisheries Cooperative database.

\subsection{Morphological Measurements}

All of the MAT and HRT sporophytes that grew on the $1 \mathrm{~m}$ long mother rope were collected from each set once every 2-3 weeks (Figure 1e,f). Then, the total wet weight of the individuals per $1 \mathrm{~m}$ of the mother rope was measured in the laboratory. The total length, sporophyte weight, and sporophyll weight of the longest 20 sporophytes were measured after removing the holdfasts.

\subsection{Photosynthesis and Nutrient Uptake Rates}

In order to quantify the photosynthesis rates and nutrient uptake rates of the MAT and HRT sporophytes, 50 individuals from MAT and HRT were removed from the set III sporelings with a razor blade on 15 January 2015, and were cultivated in the CFCS tank. After one month, 30 plants, with a total length of $<30 \mathrm{~cm}$, were collected and pre-incubated at $10{ }^{\circ} \mathrm{C}$ under a light intensity of $100 \mu \mathrm{mol}$ photons $\mathrm{m}^{-2} \mathrm{~s}^{-1}$ for $1 \mathrm{~h}$ in $30 \mathrm{~L}$ of seawater in the CFCS tank, which was installed with a thermostatic circulator pump to regulate the seawater temperature. Following the pre-incubation, the central part of the maximum blade width area was subjected to dark conditions by attaching a leaf clip (PAM-2000; WALZ, Effeltrich, Germany) for 20 min to fully oxidize the electron transport chain before conducting the measurements [25]. While the sporophytes were still in seawater, a pulse amplitude modulation (PAM) fluorimeter (MINI-PAM II; WALZ) was used to determine the effective quantum yield $\left(F_{\mathrm{v}} / F_{\mathrm{m}}\right)$ using the following equation [26]:

$$
F_{\mathrm{v}} / F_{\mathrm{m}}=\left(F_{\mathrm{m}}-F_{\mathrm{o}}\right) / F_{\mathrm{m}}
$$

where $F_{\mathrm{o}}$ is the minimum fluorescence and $F_{\mathrm{m}}$ is the maximum fluorescence. This test was conducted at seawater temperatures of $5^{\circ} \mathrm{C}, 10^{\circ} \mathrm{C}, 15^{\circ} \mathrm{C}, 20^{\circ} \mathrm{C}$, and $25^{\circ} \mathrm{C}$ using the same 30 sporophytes.

In order to quantify the nutrient uptake rates of the two strains, 3.3-cm-diameter blade discs were removed from the maximum blade-width area of five individuals from the 
MAT and HRT samples. These discs were pre-incubated in $1 \mathrm{~L}$ flasks containing aerated sterilized seawater at $10^{\circ} \mathrm{C}$ and under a light intensity of $100 \mu \mathrm{mol}$ photons $\mathrm{m}^{-2} \mathrm{~s}^{-1}$ with a $12 \mathrm{~h}$ photoperiod for $48 \mathrm{~h}$ in order to allow recovery from the wounding that had occurred during the blade disk preparation $[27,28]$. The seawater used for the pre-incubation was collected from the Sea of Japan by the Akita Prefectural Institute of Fisheries, and contained natural nutrient concentrations close to the detection limits. Each disc was transferred to a $200 \mathrm{~mL}$ flask containing $100 \mathrm{~mL}$ of sterilized and filtered seawater (GF/F filters; Whatman, Maidstone, UK). Flasks that contained seawater without sporophyte discs were used as the control. Then, $\mathrm{NO}_{3}-\mathrm{N}, \mathrm{NH}_{4}-\mathrm{N}$, and $\mathrm{PO}_{4}-\mathrm{P}$ were added to the flasks in the form of sodium nitrate, ammonium chloride, and sodium phosphate dibasic dodecahydrate, respectively, to provide initial concentrations of $15 \mu \mathrm{M} \mathrm{NO}_{3}-\mathrm{N}, \mathrm{NH}_{4}-\mathrm{N}$, and $2 \mu \mathrm{M} \mathrm{PO}_{4}-\mathrm{P}$, respectively. The flasks were then incubated at $5^{\circ} \mathrm{C}, 10^{\circ} \mathrm{C}, 15^{\circ} \mathrm{C}, 20^{\circ} \mathrm{C}$, or $25^{\circ} \mathrm{C}$, and shaken at $80 \mathrm{rpm}$ on a multi-shaker (MMS-4010; Tokyo Rikakikai, Tokyo, Japan) under a light intensity of $180 \mu \mathrm{mol}$ photons $\mathrm{m}^{-2} \mathrm{~s}^{-1}$, which was provided by white fluorescent lamps. The samples were incubated for 60 min using a previously reported method [20,22].

After $60 \mathrm{~min}$ incubation, $10 \mathrm{~mL}$ seawater samples were collected in plastic tubes and frozen until they were needed for analysis. The blade discs were dried in a convection oven (NDO-600ND; Tokyo Rikakikai) at $80^{\circ} \mathrm{C}$ for $48 \mathrm{~h}$, and their dry weights were measured. The nutrient concentrations in the seawater were determined using an automated analyzer. The $\mathrm{NO}_{3}-\mathrm{N}, \mathrm{NH}_{4}-\mathrm{N}$, and $\mathrm{PO}_{4}-\mathrm{P}$ uptake rates ( $\mu$ mol $\mathrm{g}$ dry weight $(\mathrm{dw})^{-1} \mathrm{~h}^{-1}$ ) were calculated for each disc by comparing the concentrations in the control and experimental flasks at each temperature $[20,22,29]$. The seawater used in these experiments was also collected from the Sea of Japan by the Akita Prefectural Institute of Fisheries. $Q_{10}$ values were calculated for the different temperatures using the following equation $[30,31]$ :

$$
\ln Q_{10}=10 *(\operatorname{lnNUR} 2-\operatorname{lnNUR} 1) /\left(\mathrm{T}_{2}-\mathrm{T}_{1}\right)
$$

where $T_{2}$ and $T_{1}$ are the test temperatures set in the experiments, and $\mathrm{NUR}_{2}$ and $\mathrm{NUR}_{1}$ are the nutrient uptake rates $\left(\mu \mathrm{mol} \mathrm{g} \mathrm{dw}^{-1} \mathrm{~h}^{-1}\right.$ ) at test temperatures $\mathrm{T}_{2}$ and $\mathrm{T}_{1}$, respectively.

\subsection{Statistical Analysis}

Student' s $t$-test was used to compare the morphological and physiological characteristics between the MAT and HRT strains. In contrast, the differences in the values of the nutrient uptake rates for MAT and HRT at the different seawater temperatures were analyzed using the Kruskal-Wallis test, followed by a post hoc Scheffe's test for multiple comparisons. The statistical tests were carried out using IBM SPSS Statistics (v. 23; IBM, Armonk, USA). A nonparametric procedure was used because not all of the data were normally distributed or homoscedastic. Differences were considered to be significant at a probability of $5 \%(p<0.05)$.

\section{Results}

\subsection{Environmental Conditions}

The seawater temperatures on the cultivation start dates for each set were $21.4{ }^{\circ} \mathrm{C}$ on 17 September (set I), $20.0^{\circ} \mathrm{C}$ on 9 October (set II), $18.2{ }^{\circ} \mathrm{C}$ on 19 October (set III), $15.2{ }^{\circ} \mathrm{C}$ on 6 November (set IV), and $13.1^{\circ} \mathrm{C}$ on 12 December (set V, Figure 2a). The nutrient concentrations in the seawater are shown in Figure $2 \mathrm{~b}, \mathrm{c}$. The $\mathrm{NO}_{3}-\mathrm{N}$ concentration was $0.29 \mu \mathrm{M}$ on 21 October, and increased to a maximum value of $7.66 \mu \mathrm{M}$ on 6 December. Then, it decreased until it reached $3.55 \mu \mathrm{M}$ in February, but began to increase again in February and reached $5.15 \mu \mathrm{M}$ in April. The $\mathrm{NH}_{4}-\mathrm{N}$ maximum concentration was $13.32 \mu \mathrm{M}$ on 17 September, but then decreased to undetectable levels, except for readings of $0.69 \mu \mathrm{M}$ on 9 October and $2.15 \mu \mathrm{M}$ on 6 th December. The $\mathrm{PO}_{4}-\mathrm{P}$ concentration reached a maximum value of $0.59 \mu \mathrm{M}$ on 6 December, and showed a similar overall trend to that of $\mathrm{NO}_{3}-\mathrm{N}$. 


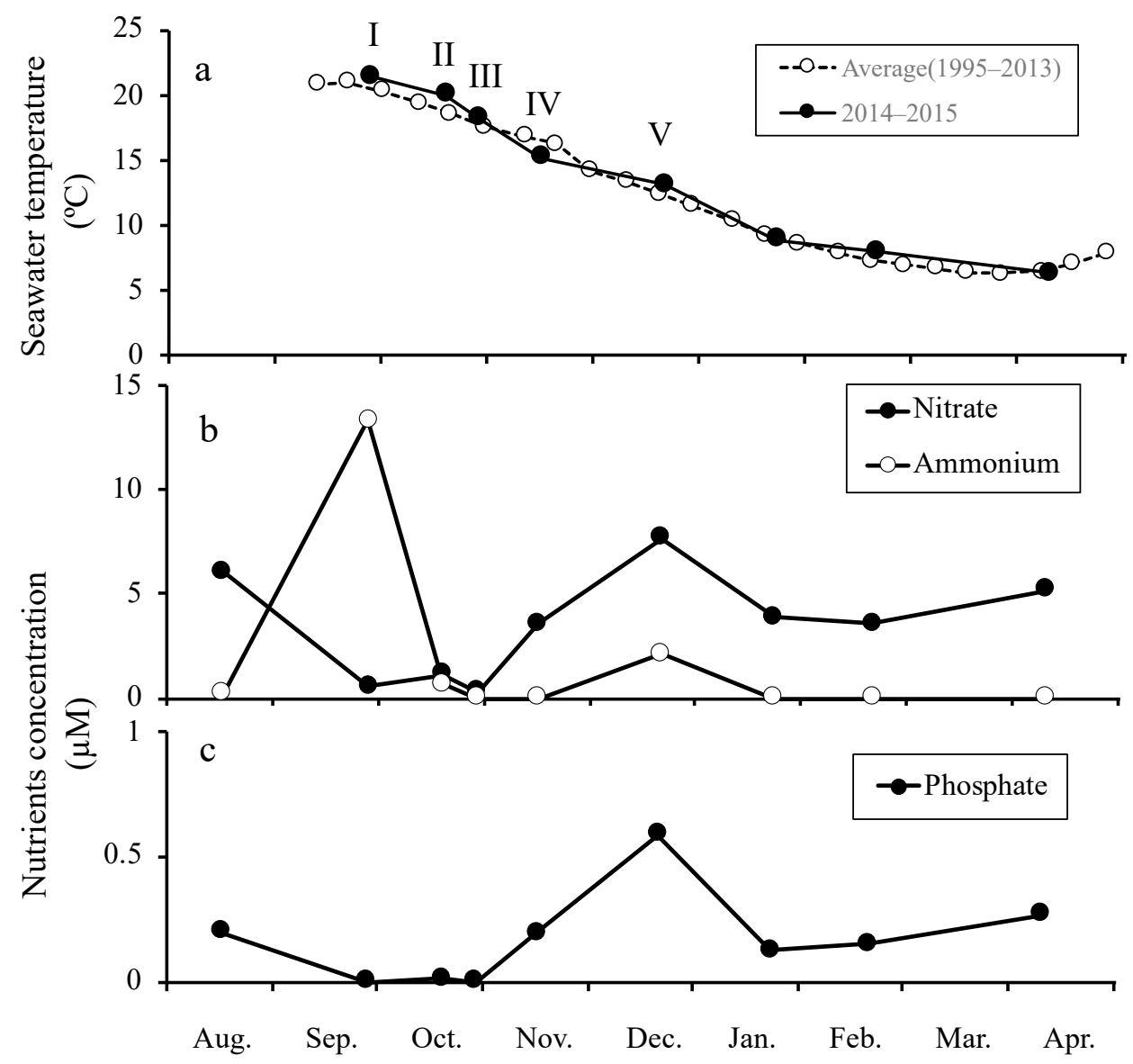

Figure 2. Changes in the environmental conditions and nutrient concentrations at Hirota Bay. (a) Seawater temperature, $(\mathbf{b})$ nitrate $\left(\mathrm{NO}_{3}-\mathrm{N}\right)$ and ammonium $\left(\mathrm{NH}_{4}-\mathrm{N}\right)$ concentrations, and $(\mathbf{c})$ phosphate $\left(\mathrm{PO}_{4}-\mathrm{P}\right)$ concentration. $\mathrm{I}-\mathrm{V}$ indicate the dates on which the sporelings were set and cultivation began (see Materials and Methods).

\subsection{Growth at the Different Dates of Cultivation Start and Yield of MAT and HRT}

The total lengths, thallus weights, and sporophyll weights of MAT and HRT on each cultivation start date (i.e., sets I-V) are shown in Figure 3. In set I, MAT and HRT grew until 30 December 2014 and 15 January 2015, respectively (Figure 3I-a,b,c); however, both strains became covered in other algae and diatoms, and could not be subsequently observed. In set II, the total length, thallus weight, and sporophyll weight of MAT were significantly higher than those of HRT after February (Figure 3II-a,b,c). Because almost the entire thalli of MAT were covered epiphytes and eroded, only HRT could be collected for measurement on 28 April. In set III, although the total length increased in almost the same pattern in the two strains, the thallus weight and sporophyll weight of MAT were significantly higher than those of HRT (Figure 3III-a,b,c). The values of the thallus weight and sporophyll weights were indicated as $2391 \mathrm{~g}$ and $447 \mathrm{~g}$ on 28 April, respectively, and these were the maximum values during the present cultivation trial (Figure 3 III- $b, c$ ). On the contrary, in set IV, the growth of HRT was superior to that of MAT, and the total length after February and the thallus and sporophyll weights on 4 April of HRT were significantly higher than those of MAT (Figure 3 IV-a,b,c). Because the thalli of MAT were eroded and covered by epiphytes in a similar manner to set $\mathrm{I}$, all of the values could not be measured on 28 April. In set $\mathrm{V}$, only HRT thalli were grown; the total length, thallus weight, and sporophyll weight were $232 \mathrm{~cm}, 975 \mathrm{~g}$, and $84 \mathrm{~g}$, respectively (Figure $3 \mathrm{~V}-\mathrm{a}, \mathrm{b}, \mathrm{c}$ ). These values were almost similar to those of HRT on April in set IV (Figure 3IV-a,b,c). 

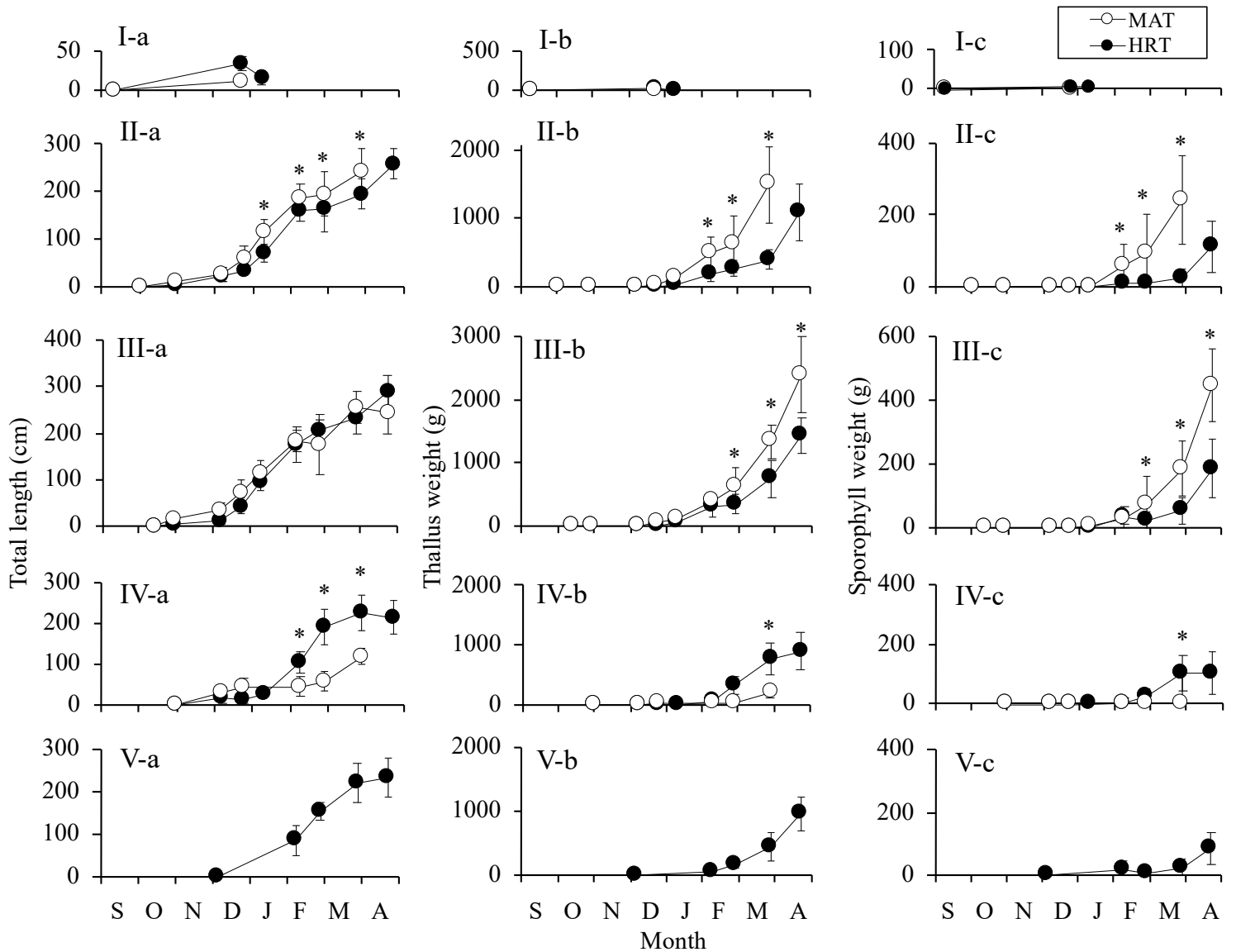

Figure 3. Changes in the total length (a), the thallus weight (b), and the sporophyll weight (c) of Undaria pinnatifida of MAT and HRT at five different dates on which the sporelings were set and cultivation began (set I-V, see Section 2, shows as I-V). The values represent the mean \pm standard deviations ( $n=20$ individuals). The asterisks indicate significant differences between MAT and HRT at $p<0.05$ according to a $t$-test.

Pictures of the typical MAT and HRT sporophytes, collected on 4 March in 2015 from set III, are shown in Figure 4. MAT had large thalli and sporophylls, whereas HRT had deeply cut thalli and smaller sporophylls than those of MAT. According to the results of the cultivation trial, the yields on $1 \mathrm{~m}$ of mother rope of MAT were higher than those of HRT (Table 1). No differences in the quality for food were observed between the MAT and HRT strains until the end of February. However, the thalli of MAT became more wrinkled on the surface and developed a coarser texture after the middle of March, whereas those of HRT remained smooth, with a good texture, until the final harvest on 28 April. On the other hand, there was no deterioration in the quality of either MAT or HRT during the harvest period for the sporophylls, despite the fact that on 28 April, and spores were obtained from the sporophylls of both MAT and HRT.

Table 1. Changes in the total wet weight of individuals per $1 \mathrm{~m}$ of mother rope $\left(\mathrm{kg} \mathrm{m}^{-1}\right)$ of MAT and HRT. Cultivation started from 19 October 2014 (set III).

\begin{tabular}{ccccccc}
\hline & \multicolumn{5}{c}{ Harvest Date } \\
\cline { 2 - 7 } & 30 December & 15 January & 13 February & 4 March & 4 April & 28 April \\
\hline MAT & 0.7 & 2.1 & 14.0 & 11.0 & 24.6 & 35.6 \\
HRT & 0.1 & 0.9 & 4.8 & 8.6 & 21.8 & 25.3 \\
\hline
\end{tabular}




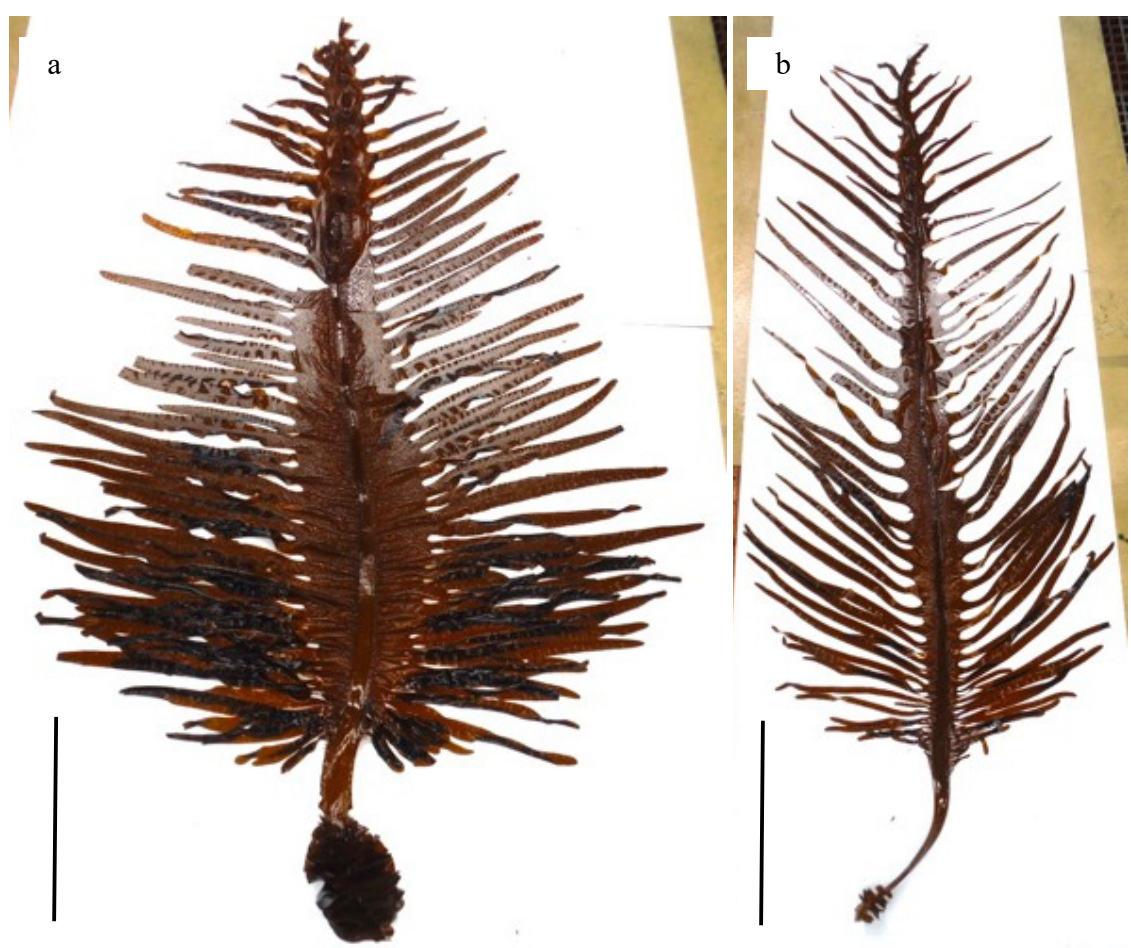

Figure 4. Photographs of typical thalli of Undaria pinnatifida. MAT (a) and HRT (b), harvested in March 2015. These thalli began to be cultivated in set III, on 19 October 2014. The scale bars are $50 \mathrm{~cm}$.

\subsection{Effects of Temperature on $F_{v} / F_{m}$ and the Nutrient Uptake Rates}

The $F_{\mathrm{v}} / F_{\mathrm{m}}$ values reached their maximum at $10{ }^{\circ} \mathrm{C}$ and $5{ }^{\circ} \mathrm{C}$ in MAT and HRT, respectively (Figure $5 \mathrm{a}$ ). The values for both strains decreased when the seawater temperature increased, but the values for MAT were significantly higher than those for HRT at all temperatures above $10{ }^{\circ} \mathrm{C}(p<0.05$, Figure 5a).

The $\mathrm{NO}_{3}-\mathrm{N}$ uptake rate of MAT was significantly affected by the seawater temperature (Supplementary Materials Table S1). The lowest uptake rate was $9.15 \mu \mathrm{mol} \mathrm{g}^{-1} \mathrm{~h}^{-1}$ at $5{ }^{\circ} \mathrm{C}$, and the highest was $26.88 \mu \mathrm{mol} \mathrm{g}^{-1} \mathrm{~h}^{-1}$ at $20^{\circ} \mathrm{C}$ (Figure $5 \mathrm{~b}$ ). In contrast, there were no significant differences between the $\mathrm{NO}_{3}-\mathrm{N}$ uptake rates of HRT irrespective of the tested temperatures (Supplementary Materials Table S1), with values ranging from 15.9 to $21.3 \mu \mathrm{mol} \mathrm{g}-1 \mathrm{~h}^{-1}$ (Figure $5 \mathrm{~b}$ ). Thus, the $\mathrm{NO}_{3}-\mathrm{N}$ uptake rates of MAT were significantly higher than those of HRT at $20^{\circ} \mathrm{C}$, but the value of HRT was significantly higher than that of MAT at $5{ }^{\circ} \mathrm{C}$ (Figure $5 b$ ).

The $\mathrm{NH}_{4}-\mathrm{N}$ uptake rates ranged between 21.8 and $31.9 \mu \mathrm{mol} \mathrm{g}^{-1} \mathrm{~h}^{-1}$ for MAT, and between 23.5 and $25.0 \mu \mathrm{mol} \mathrm{g}^{-1} \mathrm{~h}^{-1}$ for HRT. There were no significant differences among the seawater temperatures for both strains (Supplemental Materials Table S1). However, the $\mathrm{NH}_{4}-\mathrm{N}$ uptake rates of MAT were significantly higher than those of HRT at all seawater temperatures above $15^{\circ} \mathrm{C}$ (Figure $5 \mathrm{c}$ ).

The $\mathrm{PO}_{4}-\mathrm{P}$ uptake rates for MAT and HRT significantly increased as the seawater temperature rose (Supplemental Materials Table S1). They reached their maximum values of $0.52 \mu \mathrm{mol} \mathrm{g}^{-1} \mathrm{~h}^{-1}$ for MAT and $0.75 \mu \mathrm{mol} \mathrm{g}^{-1} \mathrm{~h}^{-1}$ for HRT at $25^{\circ} \mathrm{C}$ (Figure $5 \mathrm{~d}$ ). The $\mathrm{PO}_{4}-\mathrm{P}$ uptake rates for HRT were significantly higher than those for MAT above $10^{\circ} \mathrm{C}$ (Figure 5d). 


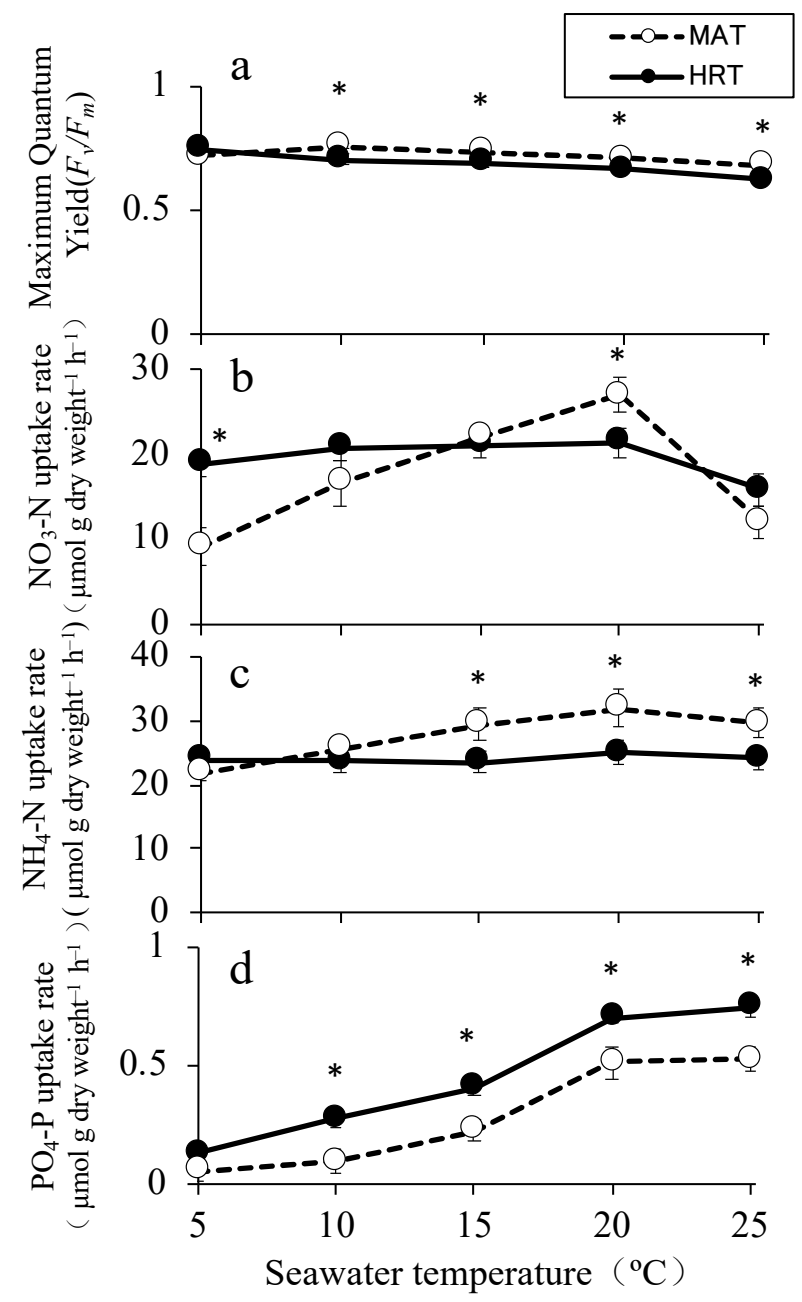

Figure 5. Maximum quantum yield $\left(F_{\mathrm{v}} / F_{\mathrm{m}}\right)(\mathbf{a})$, nitrate $\left(\mathrm{NO}_{3}-\mathrm{N}\right)$ uptake rate $(\mathbf{b})$, ammonium $\left(\mathrm{NH}_{4}-\mathrm{N}\right)$ uptake rate $(\mathbf{c})$, and phosphate $\left(\mathrm{PO}_{4}-\mathrm{P}\right)$ uptake rate $(\mathbf{d})$ in Undaria pinnatifida at different seawater temperatures. The values are means \pm standard deviations ((a): $n=30$ individuals, (b-d): $n=5$ individuals). The asterisks indicate significant differences between MAT and HRT at $p<0.05$, according to a $t$-test.

The $Q_{10}$ values for nutrient uptake differed among the nutrients, temperatures, and strains (Table 2). The $\mathrm{NO}_{3}-\mathrm{N}$ uptake rate values were 1.7 or below in all cases except for MAT, when the temperature increased from $5{ }^{\circ} \mathrm{C}$ to $10{ }^{\circ} \mathrm{C}$, whereas the $Q_{10}$ values for the $\mathrm{NH}_{4}-\mathrm{N}$ uptake rate were $\leq 1.4$ for both strains at all of the seawater temperatures. The $Q_{10}$ values for the $\mathrm{PO}_{4}-\mathrm{P}$ uptake rate were 2.2 and above for both strains at all of the temperatures except $20-25^{\circ} \mathrm{C}$. The maximum values were 6.3 at $10-15^{\circ} \mathrm{C}$ for MAT and 4.7 at $5-10{ }^{\circ} \mathrm{C}$ for HRT.

Table 2. $Q_{10}$ values for the nitrate, ammonium, and phosphate uptake rates of the MAT and HRT sporophytes. The sporophytes began to be cultured in set III (19 October 2014), and were collected on 15 January in 2015. The pre-culture was carried out in the CFCS for one month. The nutrient uptake rates were measured at $5{ }^{\circ} \mathrm{C}$ intervals from seawater temperatures of $5^{\circ} \mathrm{C}$ to $25^{\circ} \mathrm{C}$.

\begin{tabular}{ccccccc}
\hline \multirow{2}{*}{$\begin{array}{c}\text { Variables of } \\
\text { Temperature }\end{array}$} & \multicolumn{2}{c}{$\mathbf{N O}_{\mathbf{3}}-\mathbf{N}$} & \multicolumn{2}{c}{$\mathbf{N H}_{\mathbf{4}}-\mathbf{N}$} & \multicolumn{2}{c}{$\mathbf{P O}_{4}-\mathbf{P}$} \\
\cline { 2 - 7 } & MAT & HRT & MAT & HRT & MAT & HRT \\
\hline $5-10{ }^{\circ} \mathrm{C}$ & 3.3 & 1.2 & 1.4 & 1.0 & 3.1 & 4.7 \\
$10-15{ }^{\circ} \mathrm{C}$ & 1.7 & 1.0 & 1.3 & 1.0 & 6.3 & 2.2 \\
$15-20^{\circ} \mathrm{C}$ & 1.5 & 1.0 & 1.2 & 1.1 & 5.3 & 3.1 \\
$20-25^{\circ} \mathrm{C}$ & 0.2 & 0.6 & 0.9 & 0.9 & 1.0 & 1.1 \\
\hline
\end{tabular}




\section{Discussion}

\subsection{Environmental Conditions}

The seawater temperatures measured in this study were approximated to those of an average year in Hirota Bay. It was experientially shown that starting the cultivation of $U$. pinnatifida $>20^{\circ} \mathrm{C}$ in Hirota Bay causes the sporelings to wither (Susumu Ohwada, personal communication). Therefore, the fishery workers' cooperative association provides seawater temperature information to the $U$. pinnatifida producers to ensure that cultivation is started $<20^{\circ} \mathrm{C}$. In this study, the seawater temperature fell below $20^{\circ} \mathrm{C}$ in the first half of October between sets II and III. The nutrient concentration was low in September and October, except for the pulse of $\mathrm{NH}_{4}-\mathrm{N}$ in September, but increased toward spring as the seawater temperature decreased. Although there is typically a decrease in nutrients in early spring at Undaria farms in the Sanriku district due to the spring bloom of phytoplankton [32], this was not observed during the present study.

\subsection{Differences in the Growth Characteristics of MAT and HRT}

The differences in the growth pattern between MAT and HRT were revealed; the thallus and sporophyll growths of MAT were superior to those of HRT in sets II and III; on the other hand, these growths of HRT were superior to those of MAT in sets IV and V. Additionally, the tolerance for the seawater temperature at the beginning of cultivation was also different between MAT and HRT: the seawater temperature at the start of cultivation, which allows subsequent growth, was limited to $20^{\circ} \mathrm{C}$ to $18^{\circ} \mathrm{C}$ for MAT, whereas it was $20^{\circ} \mathrm{C}$ or below for HRT. Regarding the cultivation yield of $U$. pinnatifida in the Sanriku district, the standard amount is $10-20 \mathrm{~kg}$ per $1 \mathrm{~m}$ of the mother rope [33]. The yield of MAT in set III exceeded $10 \mathrm{~kg} \mathrm{~m}^{-1}$ in February, and the quality of thalli was satisfactory to market until the middle of March. On the other hand, the yield of HRT exceeded $10 \mathrm{~kg} \mathrm{~m}^{-1}$ after the beginning of April. Therefore, the proper time to begin cultivation and harvesting could be extended by using both MAT and HRT even in the same aquaculture site. Firstly, the cultivation period of MAT begins when the seawater temperature is $20-18{ }^{\circ} \mathrm{C}$, and harvesting is carried out until the middle of March. Secondly, the cultivation period of HRT begins when the seawater temperature is $20-13{ }^{\circ} \mathrm{C}$, and harvesting occurs in April. These differences in characteristics among the strains could help to distribute the concentration of the workforce in the aquaculture process of this alga. These results suggested that MAT and HRT are applicable for cultivation as an earlier maturation strain and a later maturation strain, respectively.

In the present study, both the MAT and HRT strains did not grow in set I when the seawater temperature was $21.4^{\circ} \mathrm{C}$. Therefore, if cultivation is to begin $>20^{\circ} \mathrm{C}$, selecting the mother plant from a warmer location would be necessary. For example, the strain from Naruto region, Tokushima Prefecture (southern Japan, in the Seto Inland Sea), would be appropriate as the mother plant for high-temperature tolerance, because this strain does not have a reduced survival rate at $24^{\circ} \mathrm{C}$ and has a high nitrogen accumulation ability under low-nutrient conditions [19].

\subsection{Physiological Characteristics of MAT and HRT}

The $F_{\mathrm{v}} / F_{\mathrm{m}}$ and nutrient uptake rates showed differences between MAT and HRT. The $F_{\mathrm{v}} / F_{\mathrm{m}}$ values of MAT were higher than those of $\mathrm{HRT}$ at $10-25^{\circ} \mathrm{C}$. The uptake rates of MAT in $\mathrm{NO}_{3}-\mathrm{N}$ at $20^{\circ} \mathrm{C}$ and $\mathrm{NH}_{4}-\mathrm{N}$ at $15-25^{\circ} \mathrm{C}$ were also observed to be higher than those of HRT. These results suggest that MAT has a potential for higher growth than that of HRT in the temperature region, and the characteristics may result in earlier maturation. In previous studies, we observed the $\mathrm{NO}_{3}-\mathrm{N}$ and $\mathrm{NH}_{4}-\mathrm{N}$ uptake kinetics to differ between several regional strains [20]. According to subsequent common garden experiments using the landbased tank cultivation method, $\mathrm{NO}_{3}-\mathrm{N}$ uptake kinetics with affinity to lower concentration levels may have a genetic origin [22]. Therefore, the different uptake responses in $\mathrm{NO}_{3}-\mathrm{N}$ and $\mathrm{NH}_{4}-\mathrm{N}$ between the strains in the present study might also have a genetic origin. On the other hand, the uptake rates in $\mathrm{PO}_{4}-\mathrm{P}$ of $\mathrm{HRT}$ were observed to be higher than those of 
MAT. Because the influence of the $\mathrm{PO}_{4}-\mathrm{P}$ uptake kinetics on growth and the differences in the kinetics among regional strains of $U$. pinnatifida have not been fully studied, further studies are needed.

Raven and Geider [34] previously reported that temperature influences the nutrient uptake rates via $Q_{10}$ effects on algal metabolism. It has been shown that $Q_{10}$ values of 2.0-2.5 characterize the active nutrient uptake across cell membranes, whereas $Q_{10}$ values between 1.0 and 1.2 reflect passive processes, such as diffusion, which are not significantly affected by temperature [35]. The present study shows, for the first time, the $Q_{10}$ values for the nutrient uptake rate in relation to the seawater temperature in $U$. pinnatifida. Based on the $Q_{10}$ values, the uptake kinetics in $\mathrm{NH}_{4}-\mathrm{N}$ may be involved in passive processes, and those in $\mathrm{PO}_{4}-\mathrm{P}$ may be involved in active processes. The differences in the $Q_{10}$ values in $\mathrm{NO}_{3}-\mathrm{N}$ between MAT and HRT may be due to the differences in the uptake kinetics depending on the regional strains. Similar differences in the $Q_{10}$ values among different varieties of the same species have previously been reported for Porphyra leucostica [36]. For brown macroalgae, $\mathrm{Xu}$ et al. (2011) [31] previously detected differences in the $Q_{10}$ values between nitrogen and phosphorus, and among temperature ranges in Saccharina japonica; the $Q_{10}$ values of phosphorus were higher than those of nitrogen $>10^{\circ} \mathrm{C}$, and these results are similar to those observed in this study. In further studies, the relationship between the growth characteristics and nutrient uptake kinetics in relation to the seawater temperature should be assimilated and clarified in further detail.

\subsection{Applications in the Undaria Farming Industry}

Although the MAT thalli were markedly larger than the HRT thalli in sets II and III, there was a notable deterioration in MAT after the middle of March. The thallus surface developing wrinkles is regarded as an indicator of low quality in U. pinnatifida [3,32,37]. Therefore, the optimum harvest time for MAT is before the middle of March. However, the quality of the sporophylls did not decline even in April, and it has been reported that sporophyll growth is not negatively affected by Undaria thallus excision [38]. Therefore, multiple harvesting using the thallus excision method could be carried out on MAT before the middle of March, when only the thallus should be harvested by excision at $30 \mathrm{~cm}$ above the meristem [38], and at the end of April, when sufficiently large sporophylls can be harvested.

Using a combination of both MAT and HRT, it may be possible to harvest twice a year on the same cultivation rope, because MAT cultivation could start in October, with the thalli being harvested in December as "sprout leaf". After the harvest of MAT, the HRT sporelings could subsequently be set on the mother rope, and the sporophytes could then be harvested until the end of April without quality deterioration. A higher price is paid for faster harvest times by the Undaria market [37]. In the Sanriku district, the price of young sporophytes harvested during the growth phase (December-January) as a sprouting leaf is five times higher than that of the ordinary crop [19]. Therefore, although the yield of MAT in December is about 15 times smaller than the value of the thalli in March (Table 1), harvesting in December may improve profitability through additional sales brought about by the double-cropping method.

In recent years, high waves and storms have frequently been generated along the coast of northern Japan due to rapidly developing low-pressure systems in winter [39]. These unseasonable storms have caused severe damage to Undaria sporelings during pre-cultivation or just after starting cultivation in the sea. This storm damage has reduced growth and caused a drop in viable seedlings. Against such sudden climate risks, HRT sporelings can start cultivation later; these are available to fishers whose seedlings have disappeared.

Undaria farming is a manual process, from sporeling setting through to shipping [33]. In particular, the separation of the thallus and stipes after boiling and salt storage must be carried out by hand for each individual in all the major cultivation areas of northeastern Asia. For example, in Japan, U. pinnatifida is intensively harvested from March to April, and thus the separation process must be completed before shipping. This creates an extremely 
large workload for fishermen, particularly with the recent decrease in the labor force. Therefore, extending the harvest period through the use of strains with different growth patterns may be an effective means of maintaining and increasing the production of Undaria with a limited workforce.

\section{Conclusions and Perspectives}

By comparing the MAT and HRT strains for $U$. pinnatifida in a cultivation study at an aquaculture site, it became clear that the growth pattern of both strains was different according to the seawater temperature at the beginning of cultivation. Moreover, the physiological characteristics between the two strains support these differences. These findings verified the efficiency of extending the cultivation period by the combined use of these regional strains.

Because Wakame farming at the Sanriku coast in Japan is becoming increasingly difficult year by year, a paradigm shift to higher productivity and more intensive production is required. Therefore, we must concentrate our research efforts on the development of elite cultivars and the assimilation of scientific evidence through the cultivation process, from sporeling production to the optimum period for harvest.

Supplementary Materials: The following are available online at https://www.mdpi.com/article/ 10.3390/phycology1020010/s1, Table S1. Differences in $\mathrm{NO}_{3}-\mathrm{N}, \mathrm{NH}_{4}-\mathrm{N}$, and $\mathrm{PO}_{4}-\mathrm{P}$ uptake rates between five temperatures of MAT and HRT strains of Undaria pinnatifida were cultivated in Hirota Bay, Iwate Prefecture. Data were analyzed using Kruskal-Wallis test followed by post-hoc Scheffe's test for multiple comparisons.

Author Contributions: Conceptualization, Y.S., N.F. and T.A.; methodology, Y.S. and T.H.; validation, Y.S.; formal analysis, Y.S.; investigation, Y.S. and T.H.; data curation, Y.S. and S.K.; writing—original draft preparation, Y.S.; writing_-review and editing, T.H., H.I., N.F., T.A. and S.K.; visualization, Y.S, and T.H.; supervision and project administration, T.A. and N.F. All authors have read and agreed to the published version of the manuscript.

Funding: This study was partly supported by the Formation of Tohoku Marine Science Centre Project (Technical Development That Leads to the Creation of New Industries) from the Ministry of Education, Culture, Sports, Science, and Technology of Japan to Y.S., T.H., H.I., N.F. and T.A.

Institutional Review Board Statement: Not applicable.

Informed Consent Statement: Not applicable.

Data Availability Statement: The data presented in this study are available in the article and Supplementary Material.

Acknowledgments: We thank Haruo Hosoya (Riken Vitamine Co., Ltd.), Hironobu Watanabe and Katsunori Ono (Riken Food Co., Ltd.) for their guidance throughout this research. We are very grateful to Osamu Sakuma, Tatsuya Musashi and Takahiro Saido (Iwate Prefectural Fisheries Technology Centre), and Susumu Ohwada and Osamu Hatakeyama (Hirota Bay Fisheries Cooperative) for their generous support during the field surveys. We also thank Nobuyoshi Nanba and Misaki Shinotsuka (Kitasato University) for their valuable advice and cooperation during the measurement of the nutrient concentrations. We thank Yutaka Ito, Miho Mogamiya, and Naoko Sasaki (Riken Food Co., Ltd.) for their technical support in measuring the morphological characteristics of $U$. pinnatifida. We also thank Eri Inomata (Riken Food Co., Ltd.) for the suggestions and comments which improved our manuscript.

Conflicts of Interest: All authors declare that the research was conducted in the absence of any commercial or financial relationships that could be construed as a potential conflict of interest.

\section{References}

1. Holdt, S.L.; Kraan, S. Bioactive compounds in seaweed: Functional food applications and legislation. J. Appl. Phycol. 2011, 23, 543-597. [CrossRef]

2. Wells, M.L.; Potin, P.; Craigie, J.S.; Raven, J.A.; Merchant, S.S.; Helliwell, K.E.; Smith, A.G.; Camire, M.E.; Brawley, S.H. Algae as nutritional and functional food sources: Revisiting our understanding. J. Appl. Phycol. 2017, 29, 949-982. [CrossRef] 
3. Yamanaka, R.; Akiyama, K. Cultivation and utilization of Undaria pinnatifida (wakame) as food. J. Appl. Phycol. 1993, 5, $249-253$. [CrossRef]

4. Kikunaga, S.; Miyata, Y.; Ishibashi, G.; Koyama, F.; Tano, K. The bioavailability of magnesium from Wakame (Undaria pinnatifida) and Hijiki (Hijikia fusiforme) and the effect of alginic acid on magnesium utilization of rats. Plant Foods Hum. Nut. 1999, 53, 265-274. [CrossRef]

5. Synytsya, A.; Bleha, R.; Synytsya, A.; Pohl, R.; Hayashi, K.; Yoshinaga, K.; Nakano, T.; Hayashi, T. Mekabu fucoidan: Structural complexity and defensive effects against avian influenza A viruses. Carbohydr. Polym. 2014, 111, 633-644. [CrossRef] [PubMed]

6. Maruyama, H.; Tamauchi, H.; Kawakami, F.; Yoshinaga, K.; Nakano, T. Suppressive effect of dietary fucoidan on proinflammatory immune response and MMP-1 expression in UVB-irradiated mouse skin. Planta Med. 2015, 81, 1370-1374.

7. Yoshinaga, K.; Mitamura, R. Effects of Undaria pinnatifida (Wakame) on postprandial glycemia and insulin levels in humans: A randomized crossover trial. Plants Foods Human Nut. 2019, 74, 461-467. [CrossRef] [PubMed]

8. Dellatorre, F.G.; Amoroso, R.O.; Saravia, J.; Orensanz, J.M. Rapid expansion and potential range of the invasive kelp Undaria pinnatifida in the southwestern Atlantic. Aquat. Invasions. 2014, 9, 467-478. [CrossRef]

9. Epstein, G.; Smale, D.A. Undaria pinnatifida: A case study to highlight challenges in marine invasion ecology and management. Ecol. Evol. 2017, 7, 8624-8642. [CrossRef] [PubMed]

10. Japan Fisheries Cooperative. Annual Report of Wakame in the Sanriku Region. 2021. Available online: https://www.zengyoren. or.jp/ (accessed on 15 September 2021).

11. Iwate Prefecture. 2018. Available online: http://www3.pref.iwate.jp/webdb/view/outside/s118Tokei/ (accessed on 15 September 2021).

12. Ishikawa, Y. Analysis of quantitative traits in cultured wakame for breeding. Fish Genet. Breed. Sci. 1991, 16, 19-24. (In Japanese)

13. Hara, M.; Akiyama, K. Heterosis in growth of Undaria pinnatifida (Harvey) Suringar. Bull. Tohoku Reg. Fish. Res. Lab. 1985, 47, 47-50.

14. Pang, S.J.; Hu, X.Y.; Wu, C.Y.; Hirosawa, A.; Ohno, M. Intraspecific crossing of Undaria pinnatifida (Harv.) Sur.-A possible timesaving way of strain selection. Chin. J. Oceanol. Limnol. 1997, 15, 227-235.

15. Dan, A.; Kato, S. Differences of morphology and growth between the two culture varieties originating from Undaria pinnatifida $\mathrm{f}$. distans and U. pinnatifida f. typica in Naruto Strait. Bull. Tokushima Pref. Fish Res. Ins. 2008, 6, 79-83. (In Japanese)

16. Kato, S.; Sumitomo, T.; Dan, A. Cultivar improvement of Undaria pinnatifida by crossing gametophytes originated from one zoospore. Algal Resour. 2010, 3, 205-210. (In Japanese)

17. Shan, T.F.; Pang, S.J.; Li, J.; Gao, S.Q. Breeding of an elite cultivar Haibao No.1 of Undaria pinnatifida (Phaeophyceae) through gametophyte clone crossing and consecutive selection. J. Appl. Phycol. 2016, 28, 2419-2426. [CrossRef]

18. Niwa, K.; Harada, K. Experiment on forcing cultivation of Undaria pinnatifida sporophytes in the Seto Inland Sea by using free-living gametophytes cultured in laboratory. Jpn. J. Phycol. 2016, 64, 10-18. (In Japanese)

19. Gao, X.; Endo, H.; Taniguchi, K.; Agatsuma, Y. Genetic differentiation of high-temperature tolerance in the kelp Undaria pinnatifida sporophytes from geographically separated populations along the Pacific coast of Japan. J. Appl. Phycol. 2013, 25, 567-574. [CrossRef]

20. Sato, Y.; Hirano, T.; Niwa, K.; Suzuki, T.; Fukunishi, N.; Abe, T.; Kawano, S. Phenotypic differentiation in the morphology and nutrient uptake kinetics among Undaria pinnatifida cultivated at six sites in Japan. J. Appl. Phycol. 2016, 28, 3447-3458. [CrossRef]

21. Sato, Y.; Yamaguchi, M.; Hirano, T.; Fukunishi, N.; Abe, T.; Kawano, S. Effect of water velocity on Undaria pinnatifida and Saccharina japonica growth in a novel tank system designed for macroalgae cultivation. J. Appl. Phycol. 2017, 29, 1683-1693. [CrossRef]

22. Sato, Y.; Hirano, T.; Ichida, H.; Murakami, M.; Fukunishi, N.; Abe, T.; Kawano, S. Morphological and physiological differences among cultivation lines of Undaria pinnatifida in a common garden experiment using a tank culture system. J. Appl. Phycol. 2017, 29, 2287-2295. [CrossRef]

23. Tatewaki, M. Formation of a crustose sporophyte with unilocular sporangia in Scytosiphon lomentaria. Phycologia 1966, 6, 62-66. [CrossRef]

24. Dan, A.; Ohno, M.; Matsuoka, M. Changes of the research and development on the resources of Undaria and Laminaria in the culture ground of Tokushima coasts. Bull. Tokushima Pref. Fish Res. Ins. 2015, 10, 25-48. (In Japanese)

25. White, A.J.; Critchley, C. Rapid light curves: A new fluorescence method to assess the state of the photosynthetic apparatus. Photosyn. Res. 1999, 59, 63-72. [CrossRef]

26. Genty, B.; Briantais, J.M.; Baker, N.R. The relationship between the quantum yield of photosynthetic electron transport and quenching of chlorophyll fluorescence. Biochim. Biophys. Acta. 1989, 990, 87-92. [CrossRef]

27. Sakanishi, Y.; Iizumi, H. Photosynthesis-temperature relationship of Laminaria longissima Miyabe (Laminariales, Phaeophyta). Jpn. J. Phycol. 1988, 46, 105-110. (In Japanese)

28. Hurd, C.L.; Dring, M.J. Phosphate uptake by intertidal fucoid algae in relation to zonation and season. Mar. Biol. 1990, 107, 281-289. [CrossRef]

29. Li, J.Y.; Agatsuma, Y.; Nagai, T.; Sato, Y.; Taniguchi, K. Differences in resource storage pattern between Laminaria longissima and Laminaria diabolica (Laminariaceae; Phaeophyta) reflecting their morphological characteristics. J. Appl. Phycol. 2009, 21, 215-224. [CrossRef]

30. Maag, M.; Malinovsky, M.; Nielsen, S.M. Kinetics and temperature dependence of potential denitrification in riparian soils. J. Env. Qual. 1997, 26, 215-223. [CrossRef] 
31. Xu, D.; Gao, Z.; Zhang, X.; Qi, Z.; Meng, C.; Zhuang, Z.; Ye, N. Evaluation of the potential role of the macroalga Laminaria japonica for alleviating coastal eutrophication. Biores. Tech. 2011, 102, 9912-9918. [CrossRef]

32. Nanba, N.; Fujiwara, T.; Kuwano, K.; Ishikawa, Y.; Ogawa, H.; Kado, R. Effect of water flow velocity on growth and morphology of cultured Undaria pinnatifida sporophytes (Laminariales, Phaeophyceae) in Okirai Bay on the Sanriku coast, northeast Japan. J. Appl. Phycol. 2011, 23, 1023-1030. [CrossRef]

33. Hasegawa, K.; Suzuki, S. Work analysis of harvesting and salt-preserved Wakame seaweed (Undaria pinnatifida) processing. Tech. Rept. Nat. Res. Inst. Fish Eng. 2005, 27, 61-80. (In Japanese)

34. Raven, J.A.; Geider, R.J. Temperature and algal growth. New Phytol. 1988, 110, 441-461. [CrossRef]

35. Lobban, C.S.; Harrison, P.J. Seaweed Ecology and Physiology; Press Syndicate of the University of Cambridge: Cambridge, UK, 1994; 366p.

36. Pedersen, A. The effects of temperature and nutrient concentrations on nitrate and phosphate uptake in different species of Porphyra from Long Island Sound (USA). J. Exp. Mar. Biol. Ecol. 2004, 312, 235-252. [CrossRef]

37. Sato, J. Wakame Nyumon; The Japan Food Journal: Tokyo, Japan, 2015; 164p. (In Japanese)

38. Gao, X.; Endo, H.; Yamana, M.; Taniguchi, K.; Agatsuma, Y. Compensation of the brown alga Undaria pinnatifida (Laminariales; Phaeophyta) after thallus excision under cultivation in Matsushima Bay, northern Japan. J. Appl. Phycol. 2013, 25, 1171-1178. [CrossRef]

39. Kawamura, R. Rapidly developing extratropical cyclones and their associated strong and gusty winds in northern winter. Wind Eng. 2017, 42, 5-14. (In Japanese) 